\title{
Channel response to increased and decreased bedload supply from land use change: contrasts between two catchments
}

\author{
G.M. Kondolf ${ }^{\mathrm{a}, \mathrm{b}, *}$, H. Piégay ${ }^{\mathrm{c}}$, N. Landon ${ }^{\mathrm{c}}$ \\ ${ }^{\mathrm{a}}$ Department of Landscape Architecture and Environmental Planning, University of California, Berkeley, CA 94720-2000, USA \\ ${ }^{\mathrm{b}}$ Department of Geography, University of California, Berkeley, CA 94720-2000, USA \\ ${ }^{\mathrm{c}}$ CNRS UMR 5600, 18 rue Chevreul, 69362 Lyon Cedex 07, France
}

Received 11 January 2000; received in revised form 4 April 2001; accepted 14 October 2001

\begin{abstract}
The catchments of Pine Creek, Idaho, USA $\left(200 \mathrm{~km}^{2}\right)$, and the Drôme River in the Drôme Department, France $\left(1640 \mathrm{~km}^{2}\right)$, illustrate contrasting changes in land use, bedload sediment production, and channel response. Hard-rock mining began in the catchment of Pine Creek near the end of the 19th century and, together with road construction, timber harvest, and historically heavy grazing of uplands, resulted in increased tributary bedload yield. Increased bedload migrating to the channel, combined with removal of large cedar trees on the floodplain, resulted in channel instability, which propagated downstream over a period of decades. On many reaches of Pine Creek, active channel width has increased by over $50 \%$ since 1933 . Over roughly the same time period, the Drôme River catchment was extensively reforested (after at least one century of denudation and heavy grazing) and numerous check dams were constructed on torrents to reduce erosion. As a result, the Drôme River has experienced a reduction in bedload sediment supply since the late 19th century. In addition, gravel has been extracted from some reaches. Consequently, the channel has degraded and gravel bars have been colonized with woody riparian vegetation. Channel widths in wide, braided reaches decreased from 1947 to 1970 by 60\%. On Pine Creek, channel instability has resulted in bank erosion (exposing contaminated mine tailings) and increased flood hazard. On the Drôme River, degradation has undermined bridges and embankments, and lowered the water table in areas dependent on groundwater for irrigation, resulting in loss of 6 million $\mathrm{m}^{3}$ of groundwater storage since 1960 . Though they differ in drainage area by nearly an order of magnitude, Pine Creek and the Drôme River provide an excellent contrast in that they represent two sides of an epicycle of alluvial sedimentation set off in each case by land disturbance. In both cases, the most recent channel changes, though in opposite directions, were viewed as negative by river managers. On Pine Creek, managers have removed (or protected from erosion) mine tailings, and have attempted to train the stream into a more stable channel, and most rock waste piles (the principal sediment sources) have recently been controlled. On the Drôme River, managers have prohibited gravel mining and adopted new policies to permit coarse sediment to migrate through the river system. (C) 2002 Elsevier Science B.V. All rights reserved.
\end{abstract}

Keywords: Aggradation; Degradation; Land use; River channel changes; River management; Sediment transport; Sediment sources

\section{Introduction}

${ }^{*}$ Corresponding author. Department of Landscape Architecture and Environmental Planning, University of California, Berkeley, CA 94720-2000, USA.

E-mail address: kondolf@uclink.berkeley.edu (G.M. Kondolf).
It is well established in the geomorphic literature that hillslopes and upstream reaches are closely linked to river channels downstream (Schumm, 1977), and 
that land use changes can induce channel changes downstream (Leopold et al., 1964; Gregory and Walling, 1973; Richards, 1982). Along the eastern seaboard of the US (Meade, 1982; Jacobson and Coleman, 1986) and in the midwestern US (Trimble, 1983; Jacobson, 1995), changes in sediment supply from agriculture in the 19th century and resulting channel changes have been well documented. In California, hydraulic mining from 1850 to 1884 delivered a pulse of sediment to the Sacramento river system, causing extensive downstream aggradation and widening, which was followed by gradual recovery over subsequent decades (Gilbert, 1917; James, 1991, 1994). Among the best-documented changes in channel form due to changes in flow and sediment supply from upstream are those occurring below dams on alluvial rivers, as documented by Williams and Wolman (1984). Urbanization within a catchment typically increases peak flows and alters the balance of forces in the channel (Schumm, 1977) towards channel incision (Yorke and Herb, 1978; Gregory et al., 1992). The time scales of land use change in the catchment, change in hydrologic and sediment fluxes, and consequent channel response can be variable. Where changes in coarse bedload sediment supply are involved, channel changes can lag behind catchment changes by decades because of the time required for coarse sediment pulses to migrate downstream through the river system (Madej and Ozaki, 1996).

Geomorphological systems are not often appreciated by managers and decision-makers, who are usually responsible for a discrete reach of river, and who usually consider management actions on short spatial scales (their reaches) and time scales (1-5 years). Moreover, they tend to view the channel as a stable form and tend to accept its recent condition as natural and proper. Channel changes, e.g., narrowing, widening, shifting, aggrading, or degrading, are often viewed negatively. Even small-scale changes, such as bar aggradation or bank erosion, may be considered abnormal. One reason channel change is viewed negatively is because it commonly creates conflicts with human uses developed along the river. Channel incision threatens to undermine bridges, channel migration erodes agricultural lands, aggradation reduces channel capacity and thereby increases flood risk, and increased runoff in recently urbanized areas sets off a round of incision and widening that threatens the new infrastructure. How- ever, a geomorphological perspective can help managers define policies based on a longer-term perspective, with an appreciation for the dynamic nature of river channels.

Pine Creek, Idaho, and the Drôme River, France, are contrasting examples of channel change resulting from land use changes. In both cases, river managers have responded to the channel changes by seeking to restore the channels to their previous conditions, raising interesting questions about what is "restoration" when channels respond to changed runoff or sediment yield after land use change. After a brief presentation of the study areas and the methods used, we consider the current geomorphologic trends and human interactions at the catchment scale, and the management actions at the channel scale.

\section{Study areas}

\subsection{Pine Creek}

Pine Creek drains a $200-\mathrm{km}^{2}$ basin in the St. Joe Mountains of northern Idaho, flowing into the South Fork Coeur d'Alene River at Pinehurst, about $50 \mathrm{~km}$ east of the city of Coeur d'Alene (Fig. 1). Elevations range from $660 \mathrm{~m}$ near the confluence with the South Fork Coeur d'Alene River to $1950 \mathrm{~m}$ at the drainage divide with the St. Joe River to the south. The catchment is mountainous, with relatively little flat land (all alluvial bottomlands) available for settlement or cultivation. The mountains are mostly forested, except for higher, subalpine areas and disturbed areas.

The basin is underlain by marine meta-sedimentary rocks of the Precambrian Belt Supergroup. Roughly the lower one third of the basin is underlain by the Pritchard Formation, a dark-grey to black argillite with a quartzitic zone exposed along the east edge of the basin. Except for a small outcrop of St. Regis formation (an argillite) in the southwest corner of the catchment, the rest of the basin is underlain by the Revett and Burke Formations, argillaceous quartzites that stratigraphically overlie the Pritchard Formation (Fig. 1). The streambeds of Pine Creek and its tributaries tend to be dominated by resistant quartzite blocks of the Revett and Burke Formations, which are readily identifiable in the field by their bright, whitish colors. The Pritchard Formation yields dark-colored argillite clasts, which 


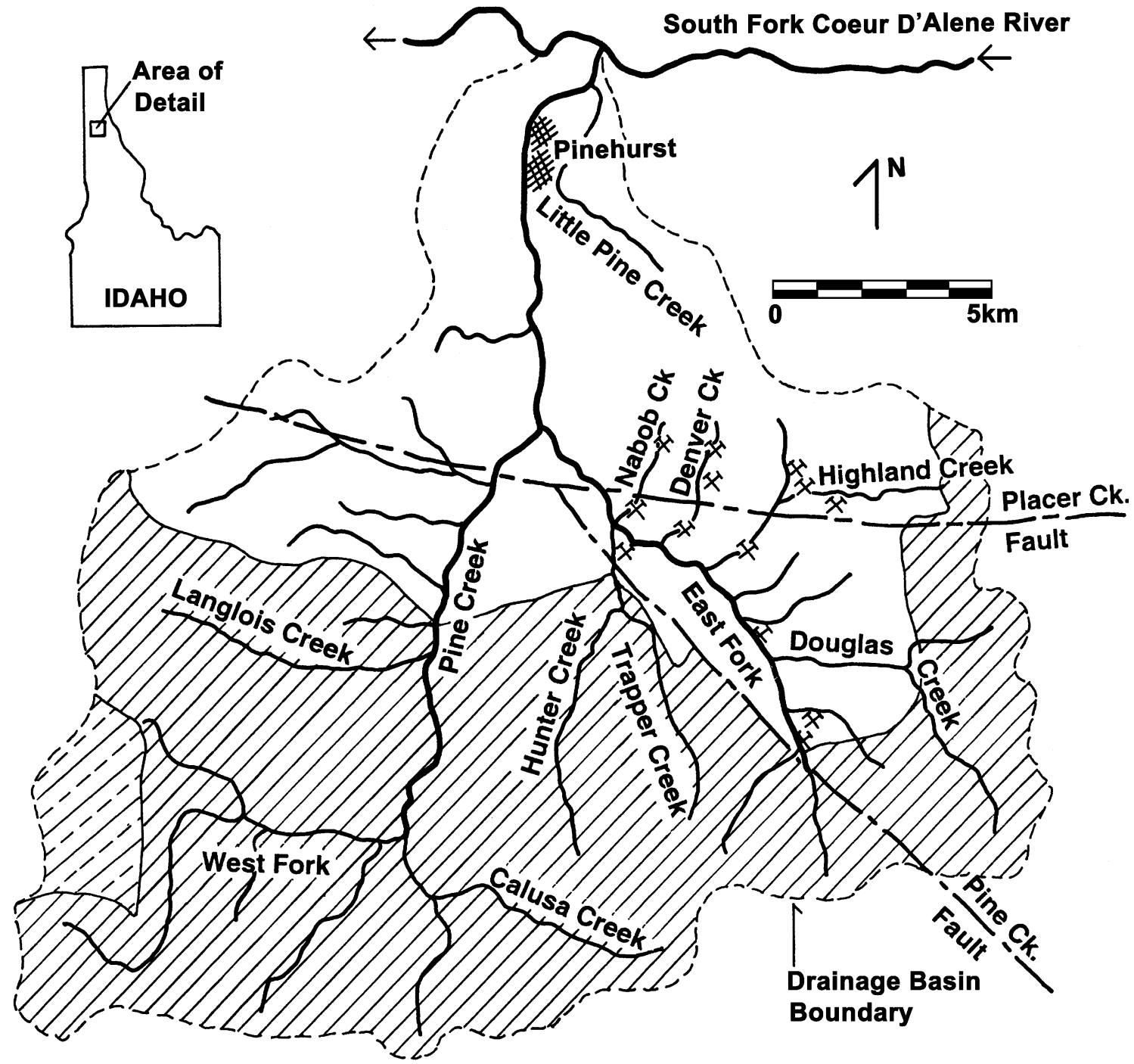

Geological Formation

\begin{tabular}{|c|c|c|}
\hline DZ Revett and Burke & Pritchard & $\because \div$ St. Regis \\
\hline $\begin{array}{c}\text { (Argillaceous } \\
\text { quartzite) }\end{array}$ & $\begin{array}{l}\text { (Dark gray } \\
\text { argillite) }\end{array}$ & $\begin{array}{l}\text { (Purplish-red- } \\
\text { green argillite) }\end{array}$ \\
\hline
\end{tabular}

Fig. 1. Location map of Pine Creek catchment, showing major tributaries and generalized geology. Pick-and-shovel symbols denote mines, the largest of which were located along eastern tributaries to the East Fork. Geology based on Jones (1919), mine locations from Mitchell (1996).

are less resistant to weathering and abrasion, and, where present, are readily distinguishable from the Revett-Burke quartzite clasts.
Pine Creek has two principal forks, which join about $10 \mathrm{~km}$ upstream of Pinehurst (Fig. 1). The West Fork drains $100 \mathrm{~km}^{2}$, with an average gradient of 0.015 in its 
main channel over a 9-km reach from the Calusa Creek confluence downstream to the confluence with East Fork. The East Fork drains about $90 \mathrm{~km}^{2}$, with an average gradient of 0.017 over the $5 \mathrm{~km}$ reach from
Masonia (Douglas Creek) to the confluence with West Fork. Annual precipitation ranges from $890 \mathrm{~mm}$ near Pinehurst to about $1520 \mathrm{~mm}$ at the divide, and Pine Creek has a unit runoff of $730 \mathrm{~mm}$.
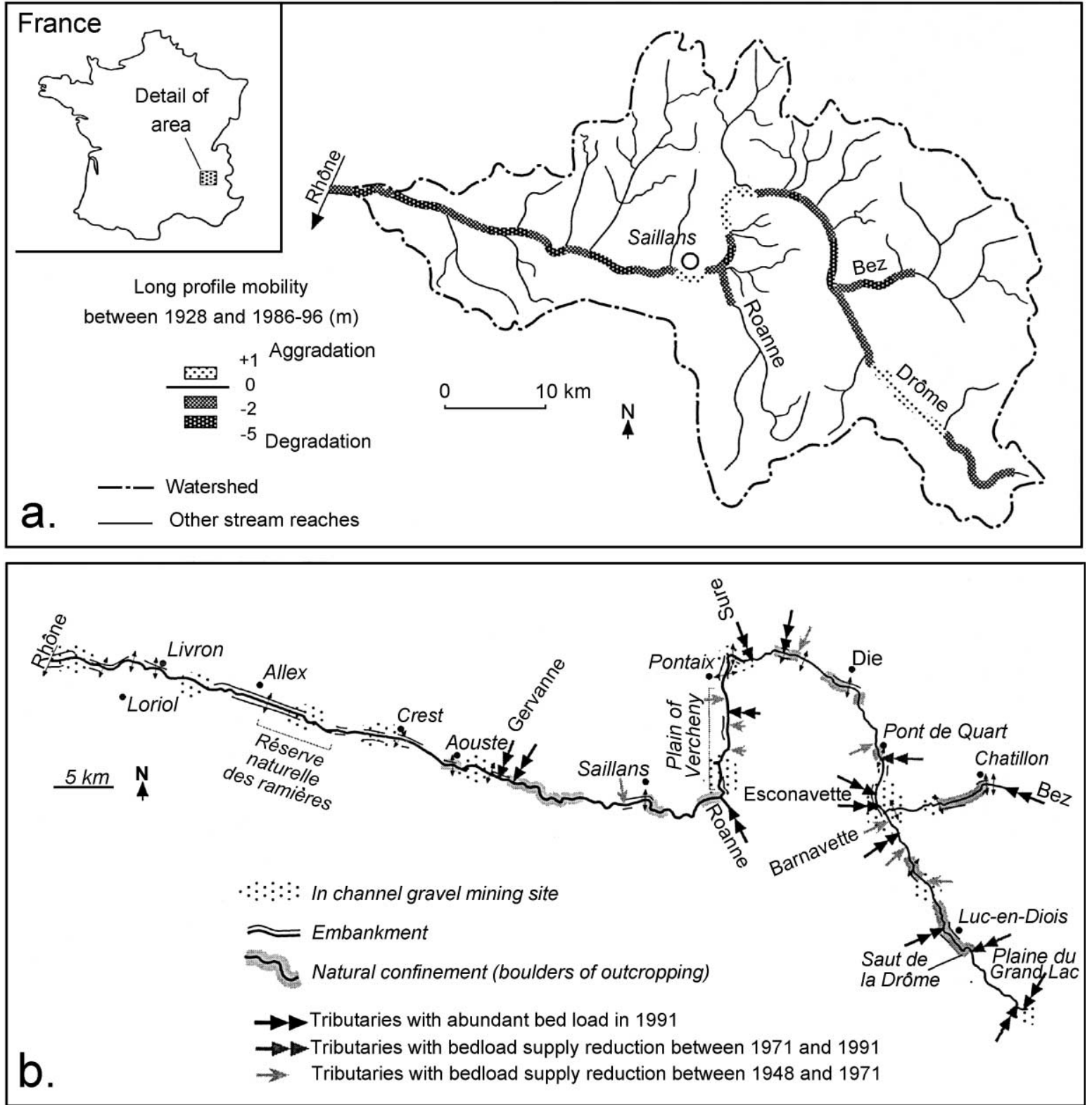

Fig. 2. Location and basin map of the Drôme River, showing post-1928 changes in bed elevation by reach (a), and map of Drôme River depicting longitudinal extent of bedrock outcrops and embankments, degradation or aggradation, and change in bedload supply from tributaries since 1948 (b). 
The Pine Creek catchment lies immediately south of the alluvial valley of the South Fork Coeur d'Alene River, known as the "Silver Valley" for the silver, lead, and other metal mines that operated there through the 1980s. Thanks to extensive mine tailings and a lead smelter (which operated for many years with inadequate pollution control devices), the Silver Valley is now the second largest "Superfund" toxic waste site in the United States. The mineralized zone extends into the Pritchard Formation in the East Fork Pine Creek catchment, with numerous mineralized veins (typically $40-60 \mathrm{~cm}$ thick) containing sphalerite, galena, pyrite, chalcopyrite, pyrrhotite, and minor amounts of silver-bearing tetrahedrite. Hard-rock mining began in Pine Creek near the end of the 19th century, with at least 10 large mines operating in the catchment (Fig. 1), the last of which closed in the 1980s (Mitchell, 1996). These mines had their greatest production in the 1940s and 1950s, spurred by wartime (and Cold War) demand for metals.

\subsection{The Drôme River}

The Drôme River drains $1640 \mathrm{~km}^{2}$ in the Vercors and Baronnies regions on the southwest flank of the Alps, flowing $106 \mathrm{~km}$ northerly and thence westward to its confluence with the Rhône $15 \mathrm{~km}$ south of Valence (Fig. 2). The catchment is underlain primarily by limestone (ridge formers) and marl (which erodes to valleys) of Cretaceous age, with elevations ranging from 800 to $1400 \mathrm{~m}$ and steep slopes. The Drôme basin marks the transition between the northern Prealps, with their rugged topography, regular folds, and extensive limestone outcrops in channels, and the southern Prealps, with their lower relief and more extensive plains. The catchment supplies a large load of sand and gravel; hence, the Drôme has a braided pattern for most of its length and forms an alluvial fan at its confluence with the Rhône. From Crest downstream, the Drome traverses its alluvial fan through agricultural lands irrigated with alluvial groundwater. The population is concentrated in this lower Rhône valley reach, from Crest (pop. 7800) to Livron (7400) and Loriol (5400).

Upstream of the Gorges of Saillans (drainage area $1147 \mathrm{~km}^{2}$ ), channel gradients are typically 0.005 to 0.01, comparable to Pine Creek, vs. 0.0025 to 0.0075 downstream of the gorges. Upstream of Saillans, the
Drôme River basin is mountainous and mostly forested although the valley bottom is intensely cultivated with orchards and vineyards. The upstream basin is also sparsely settled; the only town with a population greater than 1000 inhabitants is Die (pop. 7000). The Drôme River is one of the last major tributaries to the Rhône with a largely natural hydrologic regime. Precipitation varies from $860 \mathrm{~mm}$ near Valence to over $1400 \mathrm{~mm}$ in the headwaters (the Vercors plateau). The basin experiences a pre-Alpine and sub-Mediterranean climate, with seasonal snowmelt runoff in the spring-summer, and occasional, violent rainstorms in the autumn and spring, which produce the largest peak flows. As gauged at Saillans, average flow is $18.6 \mathrm{~m}^{3} \mathrm{~s}^{-1}$ (equivalent to $510 \mathrm{~mm}$ annual runoff from the basin), $Q_{1.5}$ is $145.7 \mathrm{~m}^{3} \mathrm{~s}^{-1}$, and the $Q_{10}$ is $380 \mathrm{~m}^{3} \mathrm{~s}^{-1}$. The northern tributaries to the Drôme, such as the Bez $\left(275 \mathrm{~km}^{2}\right)$ and the Sure $\left(73 \mathrm{~km}^{2}\right)$ drain the foothills of the Vercors massif, and their hydrology is influenced by karst groundwater and snow melt. The southern tributaries, such as the Roanne $\left(234 \mathrm{~km}^{2}\right)$, drain the lower elevation hills of the Baronnies, with peak runoff is in response to autumn rainstorms.

\section{Material and methods}

\subsection{Air photo analysis}

We compiled sequential aerial photographs available for Pine Creek from 1933, 1956, 1968, 1975, 1981, and 1991 (ranging in scale from 1:15,000 to 1:21,000); and for Drôme River from 1946-1948, 1969-1970, and 1991 (ranging in scale from $1: 18,000$ to $1: 26,000$ ). We divided the study reaches into 500-m segments, each identified by its distance $(\mathrm{km})$ upstream from the master stream (South Fork Coeur d'Alene River for Pine Creek, Rhône River for the Drôme). At the midpoint of each 500-m segment, we measured the channel width (e.g., gravel bar+low flow channel) and estimated our measurement error (from \pm 4 to $7 \mathrm{~m}$ ) depending on the scale of the photography. From these photographs, we also measured on the Drôme, for each 500-m segment, the number of wooded islands, and a braided index (ratio of total channel length to valley length). We also noted changes in catchment and channel conditions for both rivers. 


\subsection{Archival analysis}

We reviewed reports of historical events potentially influencing sediment yield to the channels, such as fires, road construction, torrent regulation, afforestation/deforestation, changes in population density, and mine development.

For Pine Creek, we reviewed records of mining operations, and computed lengths of tunnel excavated annually for individual mines based on data reported in Mitchell (1996). We estimated the volume of tunnel rock waste produced annually, assuming typical tunnel dimensions of $2.4 \times 2.0 \mathrm{~m}$ (Jim Robbins, US Bureau of Land Management Coeur d'Alene, Idaho, personal communication, December 1998). We reviewed reports of mining activity, flooding, harvest of trees, and other events potentially affecting channel conditions.

For the Drôme, we analyzed archival data concerning rural population and land use in the catchment, back to the cadastral maps of 1831 . These maps show (in detail) parcel lines and land uses, and show the bed and banks of the river. We plotted longitudinal profiles surveyed in 1928 by the Service des Grandes Forces Hydrauliques and profiles surveyed in 1986 by consultants to document bed elevation.

\subsection{Hydrologic analysis}

We also analyzed flood records for long-term gauges in region to develop long-term average flow values and flood frequency analysis. A recording stream gauge was established on Pine Creek only in the fall of 1997. Its unit runoff for water years 1998 and 1999 was $730 \mathrm{~mm}$. This was consistent with unit runoff values for longer-running gauges in the region-St. Joe River $\left(2670 \mathrm{~km}^{2}\right): 789 \mathrm{~mm}$; Placer Creek at Wallace $\left(38.6 \mathrm{~km}^{2}\right): 850 \mathrm{~mm}$; and the North Fork Coeur d'Alene River near Pritchard $\left(868 \mathrm{~km}^{2}\right): 730 \mathrm{~mm}$. Based on comparisons of annual hydrographs, we found that the North Fork Coeur d'Alene River near Pritchard, Idaho (USGS gauge no. 12411000) best mimicked the runoff patterns in Pine Creek in 1998 and 1999. Thus, we synthesized an annual maximum series for Pine Creek based on the record of annual peak flows on the North Fork Coeur d'Alene (period of record 1950-1999). For the Drôme River, we plotted annual hydrographs and developed a flood frequency analysis from gauging records at Saillans (Table 1), the reach with channel gradients comparable to those on Pine Creek. We examined long-term records for evidence of recent changes in flood frequency as a possible explanation for the observed channel change.

\subsection{Field observations and measurements}

We conducted pebble counts (Wolman, 1955; Kondolf, 1997) in Pine Creek at sites along an upstream-downstream continuum in the East Fork and Highland Creek (reflecting different degrees of impact from mining). In these pebble counts, we also recorded lithology as being Burke-Revett or Pritchard Formation. We surveyed cross sections, noting grain size and vegetative cover along the section, and cored selected trees to obtain representative ages to

Table 1

Hydrologic and channel data for Pine Creek and the upper Drôme River

\begin{tabular}{lll}
\hline & $\begin{array}{l}\text { Pine Creek } \\
\text { near Pinehurst }\end{array}$ & $\begin{array}{l}\text { Drôme River } \\
\text { upstream of Saillans }\end{array}$ \\
\hline $\begin{array}{l}\text { Drainage area }\left(\mathrm{km}^{2}\right) \\
\text { Mean flow, } Q_{\text {ave }}\end{array}$ & 200 & 1147 \\
$\quad\left(\mathrm{~m}^{3} \mathrm{~s}^{-1}\right)$ & 4.4 & 18.6 \\
Unit runoff $(\mathrm{mm})$ & 730 & 509 \\
Mean annual flood, & 44 & 235 \\
$\quad Q_{\text {maf }}\left(\mathrm{m}^{3} \mathrm{~s}^{-1}\right)$ & & \\
$Q_{2}\left(\mathrm{~m}^{3} \mathrm{~s}^{-1}\right)$ & 39 & 256 \\
$Q_{10}\left(\mathrm{~m}^{3} \mathrm{~s}^{-1}\right)$ & 69 & 381 \\
$Q_{100}\left(\mathrm{~m}^{3} \mathrm{~s}^{-1}\right)$ & 165 & 880 \\
$Q_{100} / Q_{\text {maf }}$ & 3.9 & 3.7 \\
$Q_{100} / Q_{2}$ & 4.2 & 3.4 \\
Channel width (m) & $30-70$ & $70-110$ \\
Channel gradient & $0.015-0.017$ & $0.005-0.010$ \\
$D_{50}$ bed material $(\mathrm{mm})$ & $70-80$ & $28-52$ \\
\hline
\end{tabular}

The Pine Creek gauge (Pine Creek near Pinehurst, US Geological Survey gauge no. 12413445) began operation only in Fall 1997, so the values here are based on data from the gauge "North Fork Coeur d'Alene River, above Shoshone Creek, near Pritchard, Idaho" (gauge no. 12411000), adjusted for drainage area, based on analysis of 1998 and 1999 flow data from Pine Creek and flow at three nearby gauges, which showed the North Fork had the most similar runoff patterns to Pine Creek.

The Drôme River gauge at Saillans began only in 1966, and flood frequency values here reflect the period 1966-1994. A longer record (since 1907) is available upstream at Luc en Diois (DA=194 $\mathrm{km}^{2}$ ), but the channel is not comparable due to effects of a large 14th century landslide. 
confirm changes in channel geometry (aggradation) over the studied period.

In the Drôme, we surveyed the longitudinal profile along virtually the entire lower $84 \mathrm{~km}$, identifying features such as bedrock outcrops, and compared the current bed elevations with those measured in 1928 and 1986 . We surveyed channel cross sections, conducted pebble counts on the mainstem and the major tributaries, and estimated bed mobilization frequency and bedload transport using scour chains. We mapped the extent of bank protection, levees and other embankments, bridges and other infrastructure crossings to identify reaches where incision posed a threat to infrastructure and increased risk of flooding.

\section{Results}

\subsection{Hydrology}

Hydrographs of mean daily flow (1998) and longterm mean monthly flow for Pine Creek (Fig. 3) and the Drome River (Fig. 4) show the dominance of snow melt and rain-on-snow runoff on Pine Creek, contrasted with greater dominance of rainfall-derived runoff on the Drôme. Unit runoff on Pine Creek is about $40 \%$ higher than the Drôme, though ratios of $Q_{100} / Q_{\text {maf }}$ and $Q_{100} / Q_{2}$ are similar (Table 1). Our inspection of long-term records for the two regions

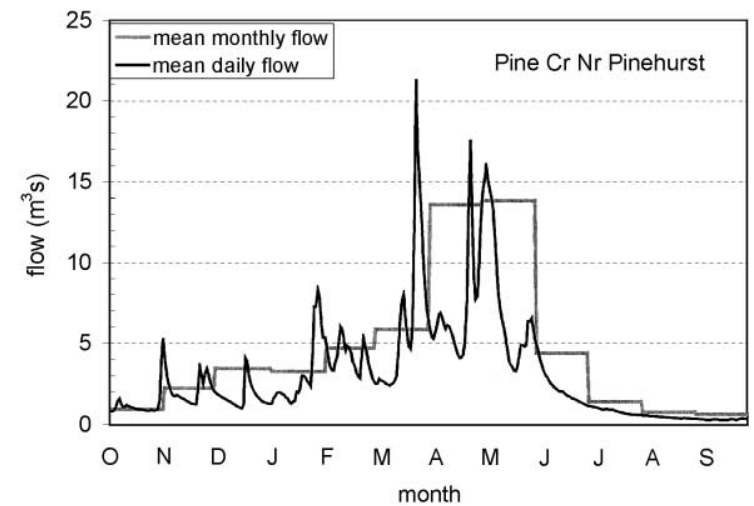

Fig. 3. Hydrographs for Pine Creek of mean daily flow for water year 1998 and long-term average monthly flows (based on North Fork Coeur d'Alene River gauging record). Both show the strong influence of snowmelt runoff. (Data from the US Geological Survey, published records.)

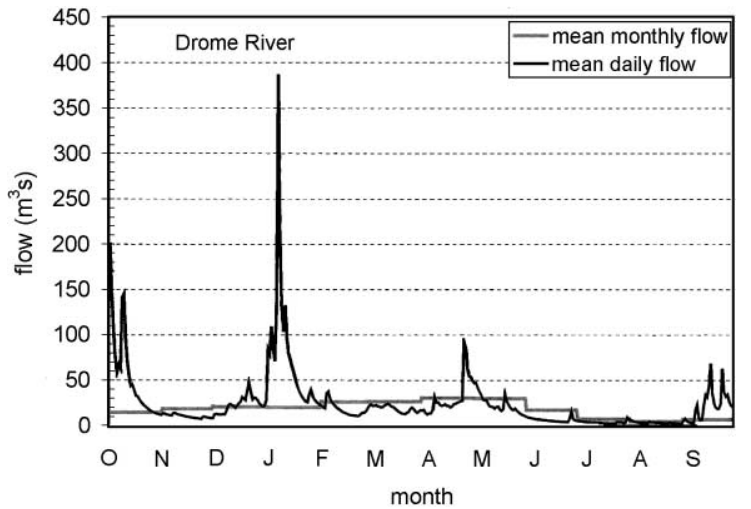

Fig. 4. Hydrographs for the Drôme River of mean daily flow for water year 1998 and long-term average monthly flows at Saillans.

did not suggest changes in flood magnitude that might explain the observed channel change.

\subsection{Channel widening on Pine Creek}

The aerial photographs of 1933 show the active channel occupied less than half of the valley bottom width, the remainder being sparsely vegetated floodplain (Fig. 5). Sparse vegetation on the floodplain probably reflected the large 1924 fire and the harvest of old growth cedars (probably around 1900). By 1956, the active channel had straightened and widened to occupy well over half of the valley bottom. Tributaries with mine development, such as Nabob, Highland, and Denver Creeks, developed alluvial fans at their confluences with the East Fork. By 1968, only scattered remnants of floodplain remained, and the unstable, active channel appeared to be migrating across most of the valley floor, conditions that persisted in the photographs of 1975 and 1984. By 1991, vegetation had established in some locations, probably reflecting the lack of large floods in preceding years, as well as a corresponding reduction in the frequency of disturbance of the entire bottomland. Average channel width on the East Fork increased from about $35 \mathrm{~m}$ in 1933 to about $75 \mathrm{~m}$ in 1956, and fluctuated between 60 and 80 $\mathrm{m}$ in width thereafter (Fig. 6). Channel widths also increased on Highland Creek, a tributary with large mines, and enlarged then contracted back to near their original dimensions on Nabob Creek. Hunter Creek, a tributary with only minor mining, but considerable 


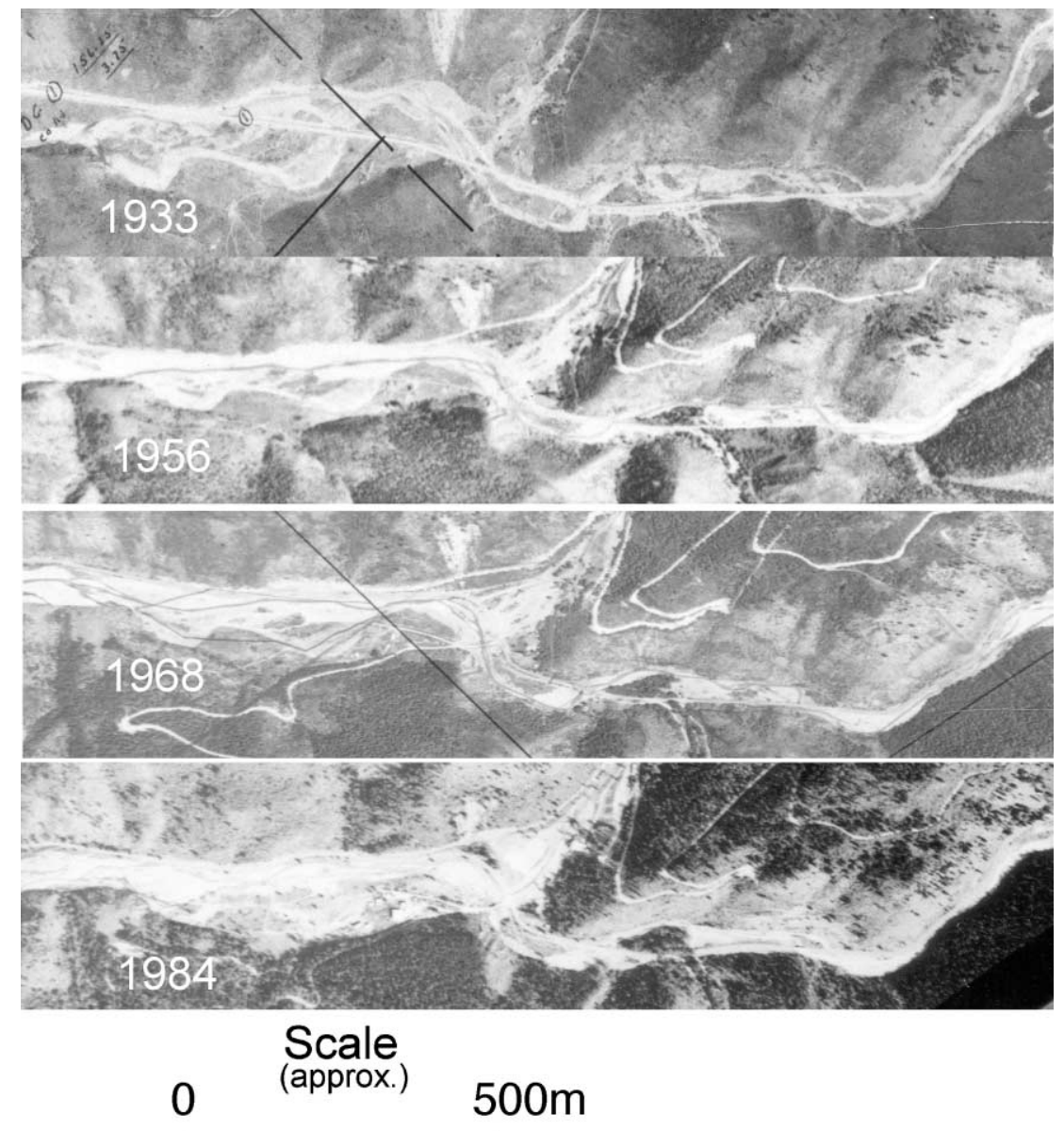

Fig. 5. Details of aerial photographs of Pine Creek from about $100 \mathrm{~m}$ below the Highland Creek confluence down to its confluence with mainstem (West Fork) Pine Creek from 1933, 1956, 1968, and 1984.

timber harvest and road development during this period, widened between 1933 and 1956, but gradually narrowed afterwards.

No historical cross sections or other bed elevation data exist to compare with current bed elevations to detect aggradation or degradation. However, from sequential aerial photographs, we can identify a few remnant floodplain areas against which to compare present bed elevations. An illustrative cross section (surveyed in May 1999) across the bottomland of the East Fork $500 \mathrm{~m}$ downstream of the confluence of Nabob Creek displays a rare remnant of floodplain, along with tree species present (Fig. 7). The left channel bed (which lacks riparian vegetation) is at virtually the same elevation as the old island surface, which is colonized by Pinus sp., and which underwent overbank sedimentation. The right bank channel is 1$2 \mathrm{~m}$ lower than the island surface and supports a diversity of riparian species. These observations suggest aggradation at this site of less than $1 \mathrm{~m}$ since 1933, resulting in a reduction in bank height between the active channel and floodplain.

\subsection{Channel incision and narrowing on the Drôme River}

Only three reaches of the Drôme River did not incise between 1928 and 1986/1995: a 4-km reach 

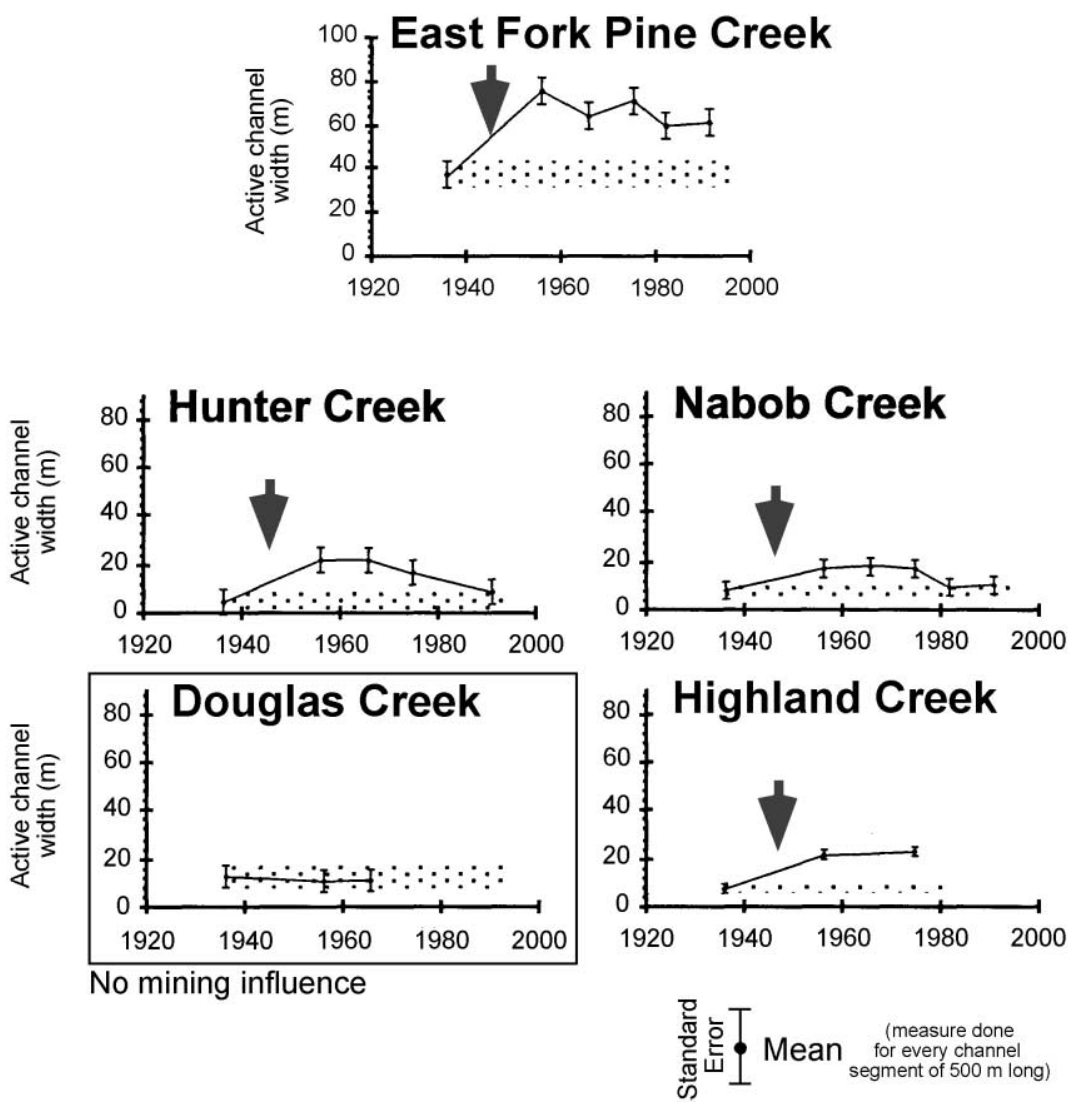

Fig. 6. Changes over time in unvegetated, active channel width for East Fork Pine Creek and its tributaries, as measured from aerial photographs. Error bars are based on precision of aerial photo measurements.

above the Pont du Quart, a 5-km reach above Pontaix, and a $4-\mathrm{km}$ reach above the Plain of Vercheny. Throughout the rest of the $100-\mathrm{km}$ length of the Drôme River, incision (locally up to $5 \mathrm{~m}$ ) was evident (Fig. 2). Incision exceeded $3 \mathrm{~m}$ over much of the reach below Pontaix, where gravel mining was concentrated. Incision of between 2 and $5 \mathrm{~m}$ was evident along $37.5 \%$ of the river length. Bedrock (limestone) outcrops are common, implying incision is now limited by bedrock.

Incision has also affected most of the tributaries. While some tributary incision is attributable to regressive erosion upstream from the mainstem Drôme, detailed field study of two tributaries (the Barnavette and the Esconavette) showed that incision affected all reaches, including those separated from the mainstem by bedrock grade controls. Average incision was 1.1 $\mathrm{m}$ on the Barnavette, $1.6 \mathrm{~m}$ on the Esconavette, less than on the mainstem Drôme, but still considerable (Liébault et al., 1999).

Besides incision, the active channel of the Drôme narrowed, as riparian trees established on the former active channel bed from 1947 to 1991, especially between 1947 and 1970 (Fig. 8). The width of the unvegetated, active channel decreased over $35 \%$, up to $60 \%$ in forested reaches such as upstream of the Réserve Naturelle des Ramières and near the confluences of the Roanne and the Bez. The braid index (total channel length per unit valley length) also decreased, reflecting disappearance of multiple channels. The number of wooded islands increased, reflecting a stabilization of in-channel bars (Fig. 8). These 


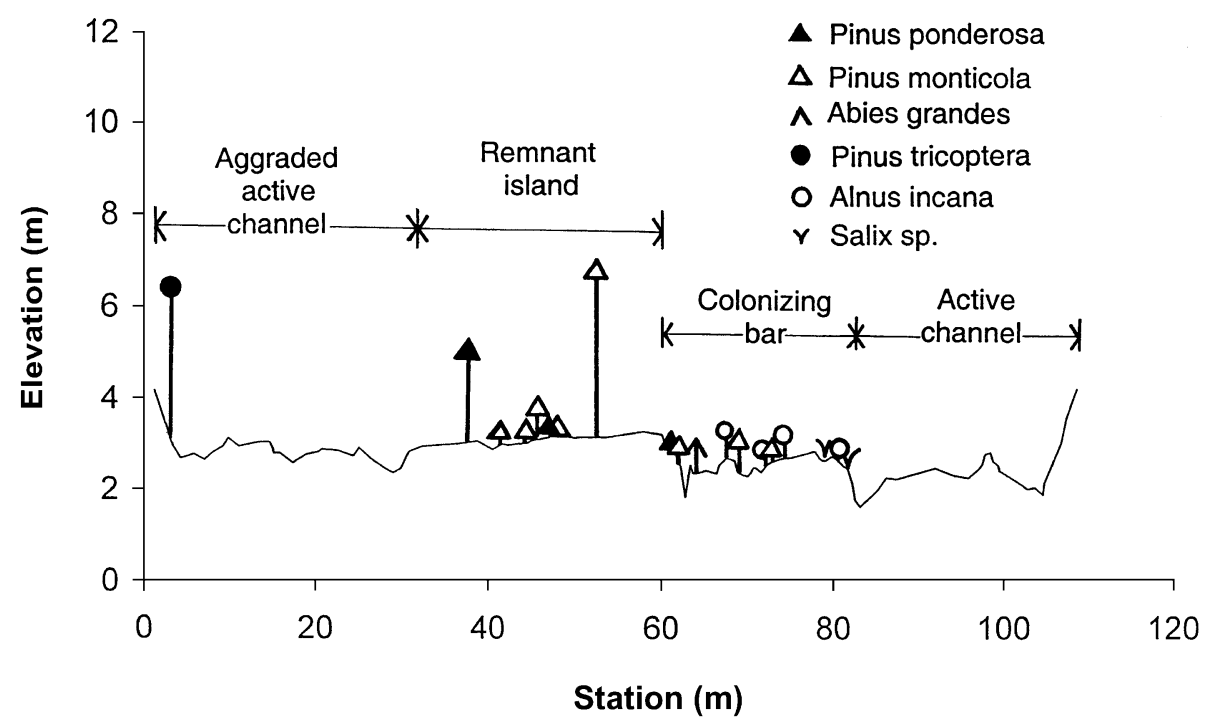

Fig. 7. Channel cross section of East Fork Pine Creek $500 \mathrm{~m}$ downstream of the Nabob Creek, crossing a remnant of the former floodplain surface, with tree heights and bed elevations shown to scale, with approximately $5 \times$ vertical exaggeration.

changes are consistent with the widely observed trend towards narrower channels favored by development of riparian forest (Montgomery, 1997).

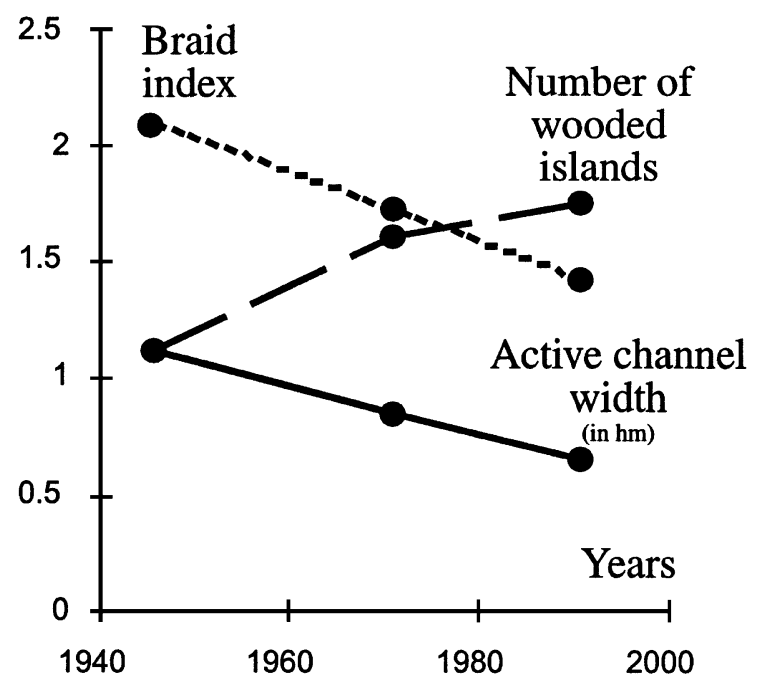

Fig. 8. Change in active channel width $\left(\mathrm{m} \times 10^{2}\right)$, braided index (channel length/valley length), and number of woody islands (per $500 \mathrm{~m}$ of channel length) along the Drôme River, as measured from aerial photographs from 1947, 1970, and 1991. (Adapted from Piégay and Landon, 1997, used by permission of Wiley.)
Tributaries also narrowed, as forests of Alnus incana, Populus nigra, and Pinus sylvestris established on former active channel surfaces. Of the 23 tributaries analyzed, nine metamorphosed from a wide channel with large gravel bars to a narrow channel with no visible gravel bars between 1947 and 1971. Another four tributaries underwent a similar metamorphosis between 1971 and 1991, while 10 still had visible gravel bars, but nonetheless narrowed somewhat. As a result of incision and vegetation encroachment (discussed below), the active channel narrowed between 1947 and 1991 (on average) from 10 to only 1-2 $\mathrm{m}$ on the Barnavette, and the gravel bars were no longer visible on air photos. On the Esconavette, the channel width decreased from 27 to $5 \mathrm{~m}$ and gravel bars were still visible (Liébault et al., 1999).

\subsection{Environmental consequences of channel change}

Channel instability and aggradation on Pine Creek have led to (1) erosion of mine tailings on the floodplain and potential mobilization of other mining-contaminated sediments, (2) erosion of the county road providing access up the East Fork, (3) increased bedload sediment delivery to downstream reaches, potentially reducing channel capacity and increasing flood risk, and (4) erosion of remnant bottomland 
forest. Managers have either removed, or protected with riprap, the concentrated piles of mine tailings, and rebuilt eroded sections of the county road. A 1-km reach of Pine Creek has been rebuilt (as a sinuous pilot channel with rebuilt floodplains) by heavy equipment in an attempt to stabilize the channel.

On the Drôme River, direct removal by gravel mining and incision (mostly due to gravel mining), have reduced the alluvial gravel in storage in the channel by about $8.1 \times 10^{6} \mathrm{~m}^{3}$ from 1928 to 1986 , an average of about $1900 \mathrm{~m}^{3} \mathrm{~km}^{-1}$ year $^{-1}$ in the reach from the Bez confluence to the Rhône (in our main study reach and downstream). Incision has undermined bridges and other infrastructure. In 1995, we documented $7.5 \mathrm{~km}$ of lateral bank protection destroyed or severely damaged by undercutting, with undercutting threatening further reaches. To stabilize the bed, 17 grade control structures have been built in the bed of the Drome, of which three appear to be destabilized. Regressive erosion has progressed up tributaries, necessitating grade control structures, many of which are now threatened with undercutting. Incision lowered the alluvial water table between 1 and $5 \mathrm{~m}$ on the alluvial fan, downstream of Crest (SOGREAH, 1991). The water table decline elimina- ted 6 million $\mathrm{m}^{3}$ of groundwater storage capacity, waters that formerly supported extensive orchards and other high-value agriculture on the Drôme floodplain (Landon et al., 1998). Loss of the gravel bed led to loss of hyporheic habitat and reduced filtration of surface water recharge to groundwater.

\subsection{Linking catchment change and channel response: Pine Creek}

Mining in the Pine Creek basin entailed road construction and timber harvest to support mine development. Most importantly, excavation of mine tunnels produced rock waste in piles adjacent to the channel, along with additional volumes of mine tailings produced at mills. The rock waste is poorly sorted, ranging in size from silt to boulders. The tailings are sand-sized and finer. Both rock waste and tailings have entered the channels of Pine Creek (Fig. 9).

When total lengths of mine shafts and tunnels reported annually (Mitchell, 1996) are summed, two principal periods of mining activity are evident (Fig. 10). Demand for lead-zinc and antimony during World War I spurred the first expansion of mines in

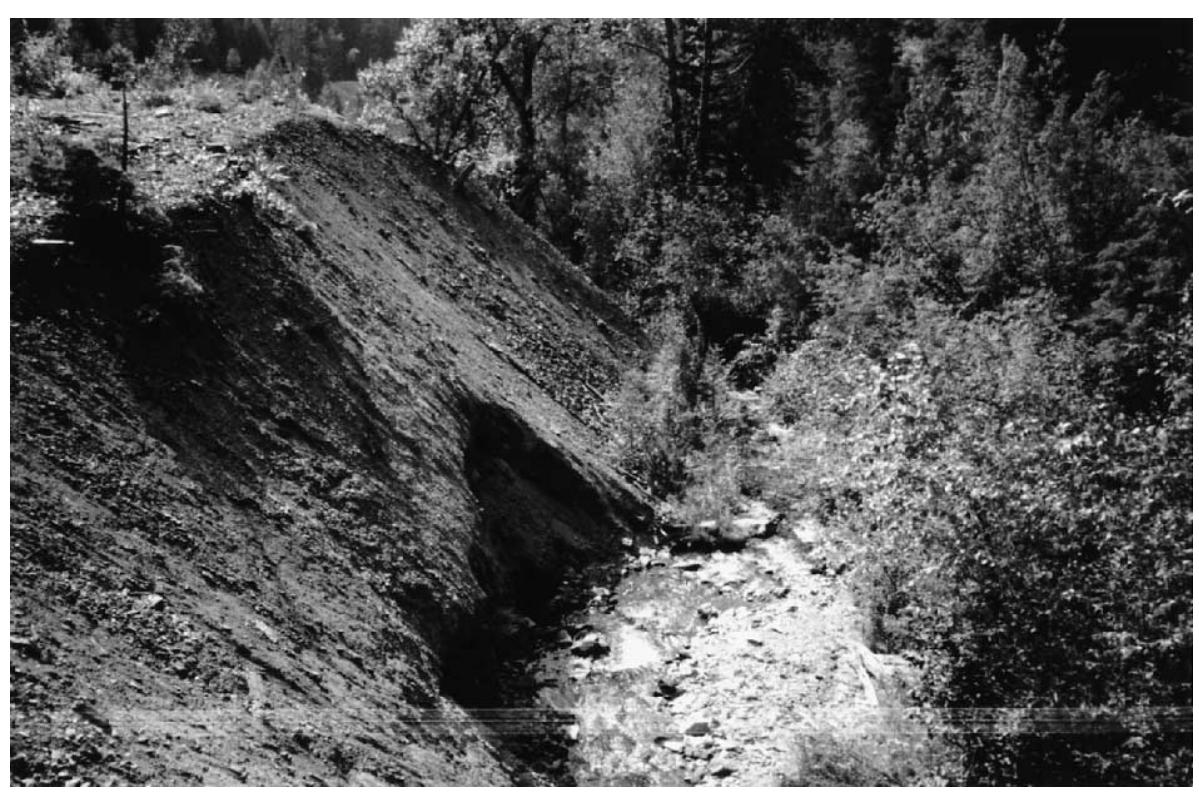

Fig. 9. Pile of mine rock waste along Highland Creek at Staranthony Mine, looking downstream along left bank. (Photo by Kondolf, 1996.) 


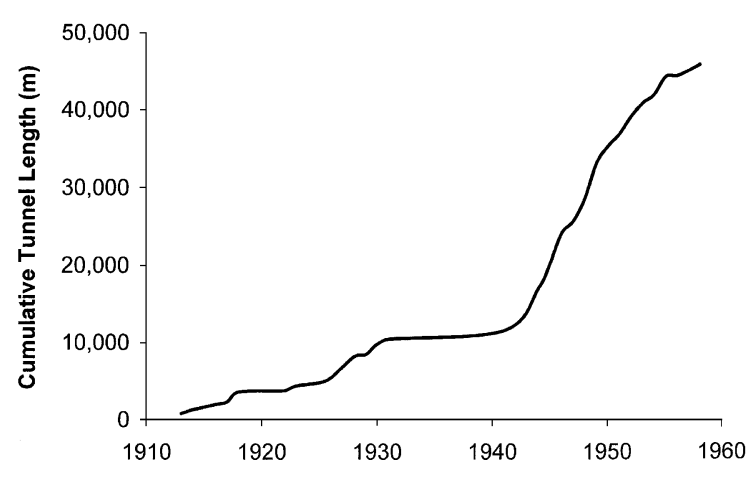

Fig. 10. Cumulative length of mine tunnels in the East Fork Pine Creek drainage, as drawn from government filings and annual reports of mining companies by Mitchell (1996). Assuming an average tunnel dimension of $2.4 \times 2 \mathrm{~m}$, at least $200,000 \mathrm{~m}^{3}$ of tunnel rock waste was piled on slopes, some of which has migrated downslope into stream channels.

the Pine Creek basin (Mitchell, 1996). From 1915 to 1930, cumulative tunnel length reached over 10,000 $\mathrm{m}$. This was followed by a prolonged period of virtual inactivity during the depression until World War II and the Cold War, when military demand for lead and zinc stimulated production in the 1940s and 1950s. Cumulative tunnel development exceeded $50,000 \mathrm{~m}$ by 1960 . The cumulative tunnel lengths indicate the production of at least $200,000 \mathrm{~m}^{3}$ of tunnel rock waste, which was piled on hillslopes below the mine entrances. Much of this waste has migrated downslope into channels. The period of time over which the East Fork Pine Creek channel widened and became unstable corresponds to the excavation of mine tunnels and thus discharge of tunnel rock waste into the channels.

Lithology of the bed material of the East Fork and its tributaries is consistent with the history of introduction of mining sediment into the channel. Outside of the influence of the mines, the bed of both forks of Pine Creek is dominated by lightcolored, chemically resistant quartzite clasts of the Burke and Revett Formations, with relatively small percentages of the darker Pritchard Formation lithologies, which are less resistant to chemical weathering (Fig. 11). However, in reaches downstream of sources of mining debris, a higher percentage of Pritchard Formation clasts occur. For example, on the main stem of the East Fork above Constitution
Mine, only $2 \%$ of the sample was from the Pritchard Formation, while below the Highland Creek confluence the percentage of Pritchard Formation rose to 29\%. Similarly, on Highland Creek itself, Pritchard clasts constituted $2 \%$ of bed material upstream of the mines, 37\% downstream of the Surprise Mine, and $73 \%$ downstream of both the Surprise and Staranthony mines (Fig. 11).

Geomorphic processes in the basin have also been influenced by fires, grazing, timber harvest, and other road construction. A fire in 1910 burned primarily ridge tops over the entire catchment, and a fire in 1924 burned only the East Fork drainage but down to the channel. We have no direct evidence of the state of the riparian vegetation along the East Fork prior to the 1924 fire, except for the anecdotal report that the oldgrowth cedars had already been cut. However, by 1933, there was relatively little riparian vegetation visible along the East Fork.

Higher elevations of the Pine Creek catchment were intensively grazed by sheep numbering more than 100,000 from the 1920 s through 1950 s. Timber

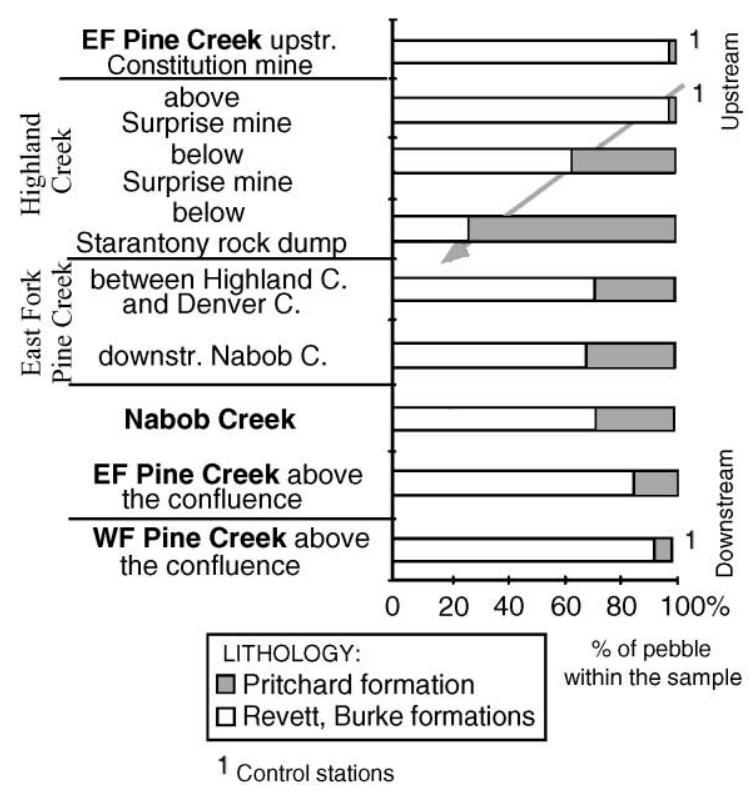

Fig. 11. Percentages of Revett-Burke Formation (quartzite) and Pritchard Formation (argillite) lithologies from pebble counts. Histograms are arranged in general upstream-downstream order, with data for Highland Creek and Nabob Creek included near their confluence points. 
(a)

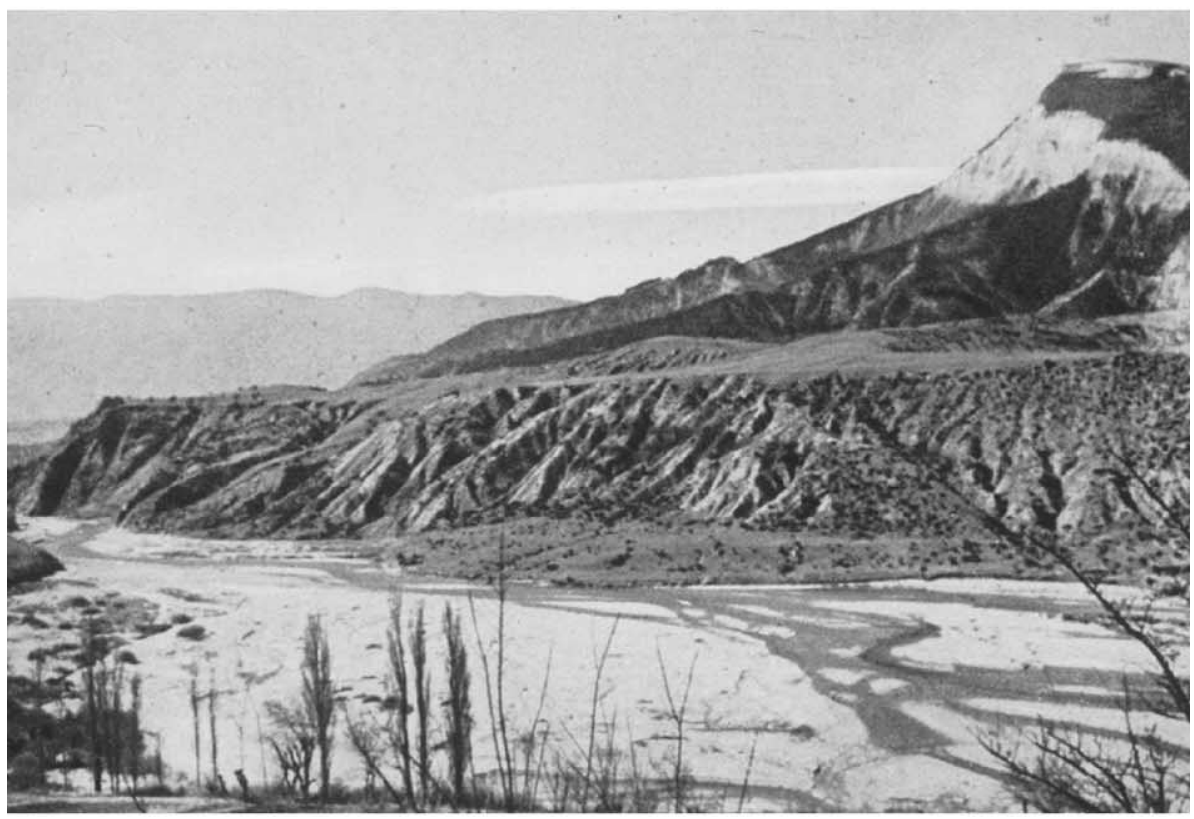

(b)

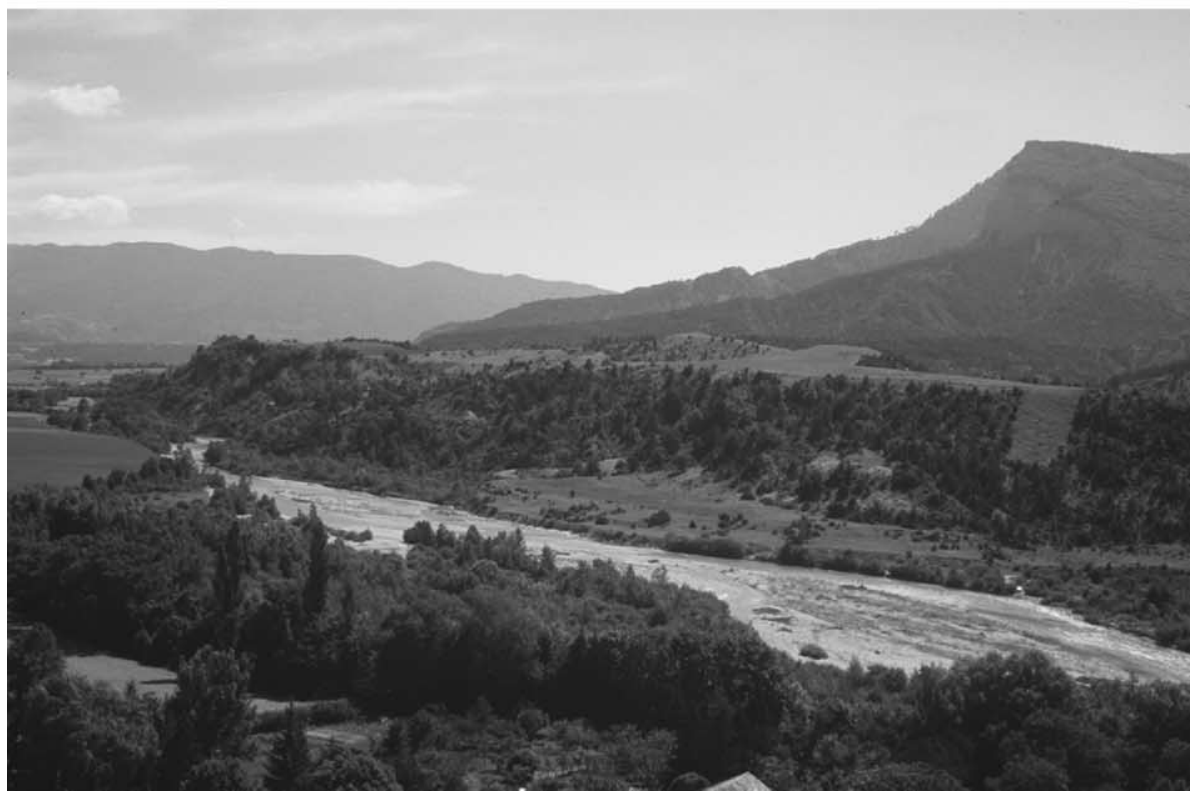

Fig. 12. View upstream to channel and adjacent left bank hillslopes of the Drôme River, $30 \mathrm{~km}$ upstream of Saillans, (a) ca. approximately 1900 , and (b) ca. 1996. The hillslopes were formerly badlands, but are now mostly forested with Pinus sp. as a result of planting by the agency Restauration des Terrains de Montagne (R.T.M.) since the $1860 \mathrm{~s}$. In the 20th century, the channel narrowed from about 300 to $150 \mathrm{~m}$ wide as a result of decreased bedload supply. (Sources: 1900 photo courtesy of R.T.M., used by permission, and 1996 photo by Landon.) 
was harvested from steep slopes, and roads constructed to access the timber, especially since the 1950s, and especially in the West Fork catchment. The lower $3.7 \mathrm{~km}$ of the West Fork was canalised (straightened, dredged, and dyked) in two phases, in 1965 and 1974, in an attempt to protect unincorporated settlements from flooding.

\subsection{Linking catchment change and channel response: the Drôme River}

The Drôme River has experienced at least three changes that would tend to induce incision: heavy mining of sand and gravel within the channel, especially downstream of Pontaix and mostly in the last 50 years (Landon and Piégay, 1994; Landon et al., 1998), dyke construction along most of the alluvial reaches of the river (which reduces sediment contributions from bank erosion and increases shear stresses in the channel), and a reduction in the supply of bedload from the catchment as a result of changed land use in the catchment. As reported above, even tributary reaches above bedrock outcrops have incised, demonstrating that in some reaches, incision cannot be explained by regressive erosion, but must be attributed to reduced sediment supply.

\begin{tabular}{|c|c|c|}
\hline \multicolumn{3}{|c|}{ Change in forest cover between 1835 and 1988} \\
\hline & Entire basin & Above Saillans \\
\hline Forest area $1835(\mathrm{ha})$ & 49246 ha & 29960 ha \\
\hline Forest area $1988(\mathrm{ha})$ & 82265 ha & 54992 ha \\
\hline Mean change $(\%)$ & $+67 \%$ & $+117 \%$ \\
\hline
\end{tabular}

Change (\%) : Minimum $=-55 \%$ (Arnayon)
Maximum $=+602 \%$ (Valdrôm
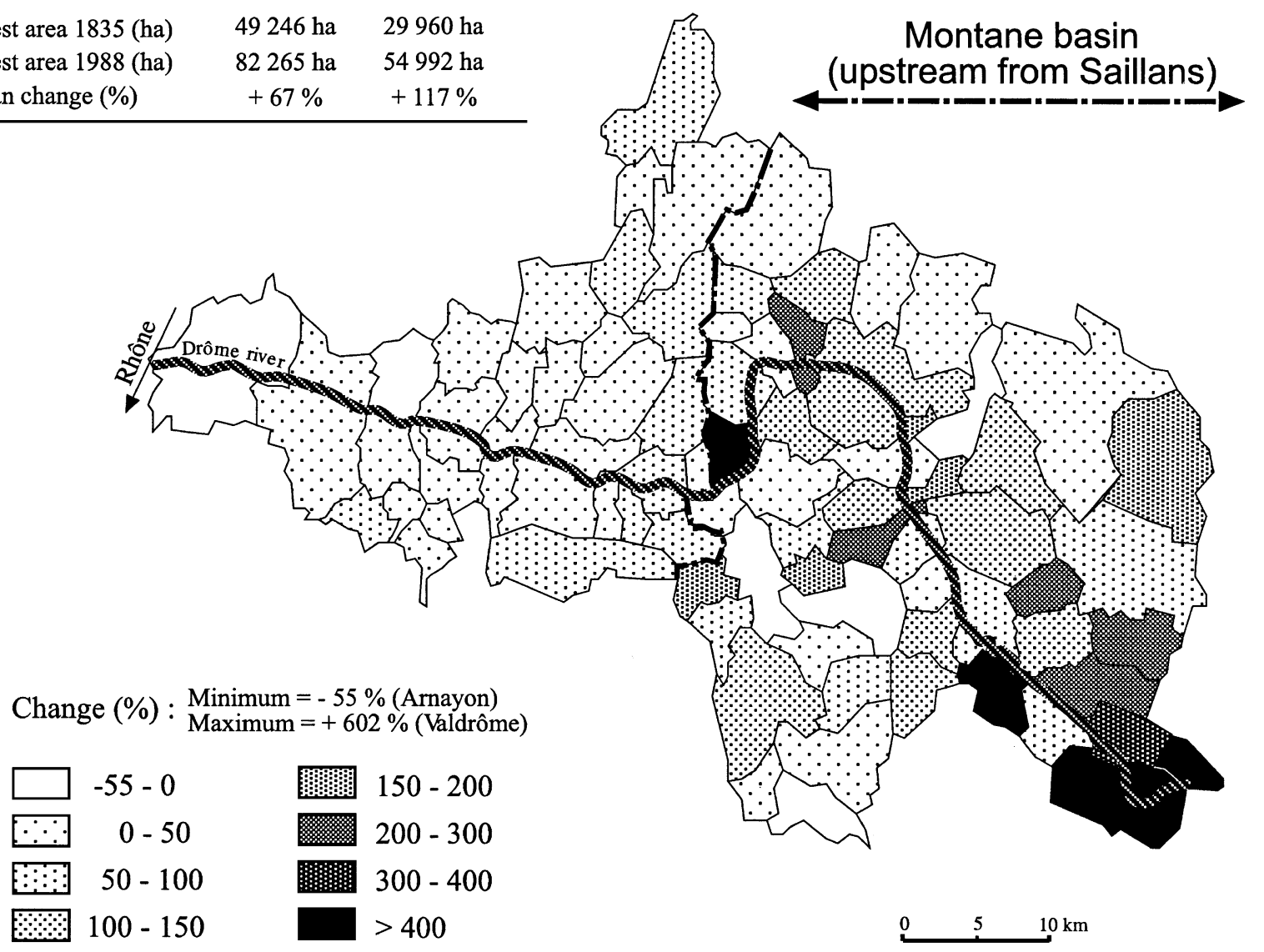

Fig. 13. Change (percentage) in forested land by commune in the Drôme River catchment from 1835 to 1988. Source: Delacroix (1835) and Institut Forestier National (1988). 
Beginning in the late 19th century, the rural population decreased with migration to cities, and the government planted trees on extensive areas that were rapidly eroding and installed check dams in high gradient channels. Many former marl badlands are now largely forested (Fig. 12). These actions resulted in a reduction in bedload sediment supply as the landscape stabilized.

Most communes in the catchment lost over half their population since the early 19th century, with the greatest declines in the steeper, most rapidly eroding areas. Parallel with the loss of population and reduced agricultural/pastoral pressure on the landscape, the area of forest increased in most of the catchment, especially in the upper, more erodible areas where state forests were established (Fig. 13). The agency Restauration des Terrains de Montagne (R.T.M.) installed 10,500 check dams or other grade controls, and cleared gravel and debris from $338 \mathrm{~km}$ of channel in the Drôme catchment (CERIC, 1975; DDA, 1994).

The channels receiving sediment from these upper slopes responded over subsequent decades to the decreased sediment supply. The tree planting and check dam construction began in the late 19th century, but the response to reduced bedload supply on downstream channels was still evident in the latter half of the 20th century. Between 1946 and 1991, most tributary channels stabilized and narrowed, and the receiving mainstem channels narrowed, formerly open braided channel bars became vegetated islands, and the degree of braiding decreased (Fig. 8).

\section{Discussion}

\subsection{Management response to channel changes: Pine Creek vs. Drôme River}

Pine Creek and the Drôme River can be viewed as two sides of an epicycle of alluvial sedimentation, set off in each case by land disturbance. The latter is a century farther on than the former (though time scale of response is a function of basin scale) so that Pine Creek today may reflect the Drôme River in the19th century. On Pine Creek, channel destabilization and widening are perceived as serious problems partly because tailings deposits have been eroded, contaminating stream flows. In addition, there is concern over potential flooding of the town of Pinehurst downstream if the channel of Pine Creek aggrades with gravel. With emergency flood repair funding (after a large flood in 1996), managers have undertaken projects to train the channel into a more stable pattern, emphasizing the use of riparian plantings, and most rock waste piles (the primary sources of accelerated sediment supply) have recently been controlled. Since 1996, the eroding tailings deposits have either been removed or protected from erosion with funds associated with cleanup of the larger Superfund site in the Coeur d'Alene River Valley to the north. Restoration of aquatic and riparian habitat has not been a prominent objective in management decisions on Pine Creek. Rather, a return to a more stable river channel and floodplain, with reduced sediment delivery to downstream reaches, is the goal.

Along the Drôme River, channel incision is viewed as a serious management problem because of the loss of groundwater storage needed by agriculture and the undermining of infrastructure. During the period of intense gravel mining, the state agency giving permits estimated permissible extraction amounts based on bedload transport equations, such as Meyer-Peter, and Muller (Vanoni, 1975). This equation predicts bedload transport capacity, which is equivalent to load only when sediment supply equals or exceeds capacity, not the case for a sediment-starved situation such as the Drôme. Moreover, miners commonly extracted more than allowed under their permits. Gravel mining is now prohibited from the channel but, with reduced bedload supply from the catchment, natural recovery will be slow at best.

Once incision was evident, the past approach along the Drôme (and similar channels) has been to prohibit mining, install grade control structures, and repair damaged infrastructure, leading to a cycle of repeated engineering interventions and progressive artificialization of the river with installation of more and more concrete and rock. In a change from past practice, managers have now adopted policies to permit coarse sediment to pass downstream through the river system in a long-term program to increase supply and aggrade the bed. For example, in 1994, a large landslide near Boulc began contributing coarse debris to the Bez, a major tributary to the Drôme. Instead of removing this debris, as would formerly have been the conventional practice, managers have chosen to leave the sediment in 


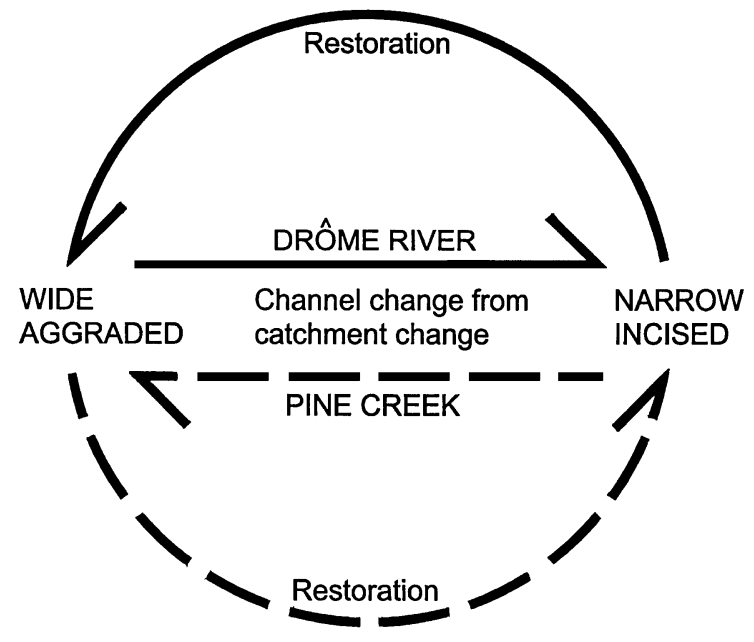

Fig. 14. Diagram illustrating contrasting directions of channel change due to catchment change, and contrasting directions of intended restoration, in Pine Creek and the Drôme River.

the channel to move downstream. In addition, managers are considering opportunities to destabilize slopes and to lower 19th century check dams to deliberately increase bedload supply to the channel downstream.

\subsection{Contrasting views of desirable channel condi- tions}

The examples of Pine Creek and the Drôme River illustrate the often complex links between human action, catchment processes, and channel form. Restoration actions on Pine Creek are designed to reduce bedload supply and make the channel narrower and more stable, while restoration on the Drôme involves increasing bedload supply and returning to a wider, braided channel (Fig. 14). Why the difference? In both cases, river managers have resisted change, in part because of conflicts with human adjustments to the previously existing condition. Differences are illustrated in Table 2. On Pine Creek, erosion of floodplain deposits and downstream flooding are important issues because of the contaminated tailings on the floodplain and because the narrow floodplains, confined by steep valley walls, make human settlement vulnerable to flood damage. There is no broad floodplain and no agriculture relying on a large alluvial aquifer, so channel incision is not viewed as a problem. On the Drôme River, channel incision has caused loss of groundwater storage and undermining infrastructure, so restoration of coarse sediment supply is viewed as a priority.

The reaction of river managers to channel change illustrates that there is no one desirable channel form, but what is considered "desirable" is influenced by the history of human occupation and the conditions to which humans have become accustomed. More fundamentally, this response illustrates the human tendency to react to rivers at the reach scale and over short time scales and to resist negative effects of channel change, rather than taking a long-term perspective that recognizes catchment processes.

\section{Acknowledgements}

Mike Stevenson of the Bureau of Land Management (BLM), Coeur D'Alene, provided access to historical aerial photographs of Pine Creek and, with Casey Friese, surveyed the channel cross section shown in Figure 7. Graham Matthews contributed to 1996 field work, historical studies, and insights into geomorphic processes in the Pine Creek catchment. David Fortier (BLM, Coeur D'Alene) provided background information on the history and natural features in the Pine Creek catchment. Vicki Mitchell (Idaho Department of Mines and Geology) and Jim Robbins

Table 2

Management goals and channel characteristics on Pine Creek and the Drôme River

\begin{tabular}{lll}
\hline Management goal & Channel characteristic & Application to case studies \\
\hline Maintain groundwater storage & Control incision & Important on Drôme, not Pine Creek \\
Do not undermine structures & Wide, active channel & Important on Drôme, not on Pine Creek \\
More complex riparian habitat & Wide, active channel & Important on Drôme, not Pine Creek because Pine Creek in narrow valley \\
Maintain channel capacity & Control aggradation & Important on Pine Creek, not Drôme because Drôme has excess capacity \\
Avoid release of contaminants & Reduce bank erosion & Important on Pine Creek due to tailings \\
\hline
\end{tabular}


(BLM, Coeur D'Alene) provided background information on historical mining practices in the Pine Creek catchment. The review comments of Mike Church, Dave Montgomery, and an anonymous reviewer substantially improved the manuscript.

\section{References}

CERIC, Cabinet RUBY, 1975. Vallée de la Drôme: étude hydraulique, prélèvement de graviers, schéma d'aménagement (Study of hydrology, gravel extraction, and management plan), with report, long profiles, and maps.

Delacroix, M., 1835. Statistiques du département de la Drôme (Statistics for the Department of the Drome) Imprimerie Borel, Crest 696 pp.

Direction Départementale de l'Agriculture et de la Forêt de la Drôme, Office National des Forêts (DDA), 1994. Enquête R.T.M.: État des lieux et estimation des besoins (Inquiry into the State of Sites and Assessment of Needs for the Agency for Restoration of Mountainous Terrains) 60 pp., with maps and appendices DDA, Valence.

Gilbert, G.K., 1917. Hydraulic mining debris in the Sierra Nevada. U.S. Geol. Surv. Prof. Pap. 105, 154 pp.

Gregory, K.J., Walling, D.E., 1973. Drainage Basin Form and Process. Edward Arnold, London, 458 pp.

Gregory, K.J., Davis, R.J., Downs, P.W., 1992. Identification of river channel change due to urbanization. Appl. Geogr. 12, $299-318$.

Institut Forestier National, 1988. Inventaire forestier national, database report.

Jacobson, R.B., 1995. Spatial controls on patterns of land-use induced stream disturbance at the drainage-basin scale: an example from gravel-bed streams of the Ozark plateaus, Missouri. In: Costa, J.E., Miller, A.J., Potter, K.W., Wilcock, P.R. (Eds.), Natural and Anthropogenic Influences in Fluvial Geomorphology. Geophys. Monogr., vol. 89. American Geophysical Union, Washington, DC, pp. 219-239.

Jacobson, R.B., Coleman, J.C., 1986. Stratigraphy and recent evolution of Maryland piedmont flood plains. Am. J. Sci. 286, 617-637.

James, A., 1991. Incision and morphologic evolution of an alluvial channel recovering from hydraulic mining sediment. Geol. Soc. Am. Bull. 103, 723-736.

James, L.A., 1994. Channel changes wrought by gold mining: northern Sierra Nevada, California. J. Am. Water Resour. Assoc. $30,629-637$.
Jones Jr., E.L., 1919. A reconnaissance of the Pine Creek district, Idaho. U.S. Geol. Surv. Bull. 710-A, 36 pp.

Kondolf, G.M., 1997. Application of the pebble count: reflections on purpose, method, and variants. J. Am. Water Resour. Assoc. $33,79-87$.

Landon, N., Piégay, H., 1994. L'incision de deux affluents subméditerranéens du Rhône: la Drôme et l'Ardèche. Rev. Geogr. Lyon 69, 63-72.

Landon, N., Piégay, H., Bravard, J.P., 1998. The Drôme river incision (France): from assessment to management. Landscape Urban Plann. 43, 119-131.

Leopold, L.B., Wolman, M.G., Miller, J.P., 1964. Fluvial Processes in Geomorphology. Freeman, San Francisco, 522 pp.

Liébault, F., Clément, P., Piégay, H., Landon, N., 1999. Assessment of bedload supply potentiality from the tributary watersheds of a degraded river: the Drôme (France). Arct., Antarct. Alp. Res. 31, 108-117.

Madej, M.A., Ozaki, V., 1996. Channel response to sediment wave propagation and movement, Redwood Creek, California, USA. Earth Surf. Processes Landforms 21, 911-927.

Meade, R.H., 1982. Sources, sinks, and storage of river sediment in the Atlantic drainage of the United States. J. Geol. 90, 235-252.

Mitchell, V., 1996. Inventory of Mines in the Pine Creek Basin. Idaho Department of Mines and Geology, Moscow, ID, 309 pp.

Montgomery, D.R., 1997. What's best on banks? Nature 388, $328-$ 329.

Piégay, H., Landon, N., 1997. Promoting ecological management of riparian forests on the Drôme River, France. Aquat. Conserv.: Mar. Freshwater Ecosyst. 7, 287-304.

Richards, K., 1982. Rivers: Form and Process in Alluvial Channels. Methuen, London, $358 \mathrm{pp}$.

Schumm, S., 1977. The Fluvial System. Wiley, New York, 338 pp.

SOGREAH, 1991. Etude diagnostic de la nappe de la basse vallée de la Drôme. Direction Départementale de l'Equipement de la Drôme, 20 pp.

Trimble, S.W., 1983. A sediment budget for Coon Creek Basin in the Driftless Area, Wisconsin, 1853-1979. Am. J. Sci. 283, 454-474.

Vanoni, V. (Ed.), 1975. Sedimentation Engineering. American Society of Civil Engineers, New York, 745 pp.

Williams, G.P., Wolman, M.G., 1984. Downstream effects of dams on alluvial rivers. U.S. Geol. Surv. Prof. Pap. 1286, 83 pp.

Wolman, M.G., 1955. The natural channel of Brandywine Creek. U.S. Geol. Surv. Prof. Pap. 271, 56 pp.

Yorke, T.H., Herb, W.J., 1978. Effects of urbanization on streamflow and sediment transport in the Rock Creek and Anacostia river basins, Montgomery County, Maryland, 1962-74. U.S. Geol. Surv. Prof. Pap. 1003, 63 pp. 